\title{
Psikolojik Danışmanların Yeterliklerinin İncelenmesi
}

\section{Metin TAYTAŞ*, Fuat TANHAN**}

Öz. Bu çalışmada, psikolojik danışmanların yeterlik algıları ile psikolojik danışmanlarının yeterliğine ilişkin öğretmen algıları sosyo-demografik değişkenler çerçevesinde incelenmiştir. $\mathrm{Bu}$ amaçla okul psikolojik danışmanlarının kendilerini ne derece yeterli gördükleri algısı ile öğretmenlerin okul psikolojik danışmanlarını ne derece yeterli gördükleri algısı ölçülüp psikolojik danışmanların yeterliği değerlendirilmek istenmiştir. Çalışma, genel tarama yöntemlerinden betimsel ve ilişkisel tarama modeli niteliğindedir. Psikolojik danışmanların yeterliğine ilişkin algıyı belirlemek için evren; Van ilinde görev yapan okul psikolojik danışmanları ile öğretmenlerden ibarettir. Araştırmanın birinci örneklemi araştırmaya gönüllü olarak katılan 79 kadın ve 115 erkek olmak üzere toplam 194 psikolojik danışmandan oluşmaktadır. Araştırmanın ikinci örneklem grubu ise bu evrenden seçilen 192 erkek ve 108 kadın olmak üzere toplam 300 öğretmenden oluşmuştur. Psikolojik danışmanlara ve öğretmenlere "Psikolojik Danışman Yeterlik Algısı Ölçeği” ve "Kişisel Bilgi Formu" uygulanmıştır. Elde edilen veriler SPSS programında analiz edilmiştir.

Anahtar Kelimeler: yeterlik, yeterlik algısı, psikolojik danışman

\section{Investigation of The Competence of Psychological Counselors}

Abstract. The study aims to examine the perceptions of psychological counselors 'efficacy and teachers' perceptions of the efficacy of psychological counselors within the framework of sociodemographic variables. For this purpose, the perception of school psychological counselors about their own competent and the perception of teachers as to how competent they regard the

\footnotetext{
*Bu makale, birinci yazarın "Psikolojik danışmanların yeterlik algısının incelenmesi” adlı yüksek lisans tezinden uyarlanmiștır.

*Uzm. Psk. Dan. Milli Eğitim Bakanlığı, Van, Türkiye. e-mail: metintaytas@gmail.com , Orcid No: 0000-00033585-7357

**Prof. Dr. Van Yüzüncü Yıl Üniversitesi, Eğitim Fakültesi, Eğitimde Rehberlik ve Psikolojik Hizmetler Anabilim Dalı. Van, Türkiye. e-mail: fuad65@gmail.com . Orcid No:0000-0002-1990-4988

***Bu araştırmanın verileri 2020 den önce toplandığı için yayın etik kurulu izni alınmamıştır.
}

\begin{tabular}{lll}
\hline Gönderim:05.11.2020 Kabul:03.01.2021 & Yayın:25.02.2021
\end{tabular}


YYÜ Eğitim Fakültesi Dergisi (YYU Journal of Education Faculty), 2021; 18(1)476-493,http://efdergi.yyu.edu.tr.

school counselors were measured and thus the competence of psychological counselors was aimed to be evaluated. The study is a descriptive and relational scanning model, one of the general scanning methods. To determine the perception of the competence of psychological counselors; School psychological counselors and teachers working in the province of Van were selected as the universe of the study. The first sample of the study consists of 194 psychological counselors, 79 female and 115 male, who voluntarily participated in the study. The second sample group of the study consisted of a total of 300 teachers, 192 males and 108 females selected from this population. "Psychological Counselor Competency Scale" and "Personal Information Form" were applied to psychological counselors and teachers. The data obtained were analyzed in the SPSS program.

Keywords: proficiency, competence perception, psychological counselor

\section{Giriş}

Birey ve toplumların gelişmesinde en önemli faktörlerden biri eğitimdir. Bu alanda uğraş veren öğretmenler ise öğrencilerin davranışlarını değiştiren ve geliştiren kişiler olarak eğitim sisteminin vazgeçilmez unsurlarıdır. Bir eğitim sisteminin başarısı, o sistemi hayata geçirip uygulayacak olan öğretmenin başarısından ayrı değerlendirilemez.

Eğitim iletişimsel bir süreci kapsar. İkili ilişkilerde karşılıklı anlayış iletişim sürecini güçlendirir. Tarafların yeterlik algıları iletişim süreci üzerinde etkilidir. Şahin’ e (2004) göre yeterlik kavramı; bireyin mesleğini yürütürken mesleğin gerektirdiği kriterleri gerçekleştirebilmek için sahip olması gereken bilgi, beceri, anlayış ve tutumları ifade etmektedir. Belirlenen eğitim hedeflerine ulaşabilmek için bireylerin sahip olması ve öğretmeöğrenme süreçlerinde kullanması gereken özelliklerin hepsi bireylerin yeterlik alanlarını oluşturmaktadır. Atıcı (2005) yeterliği, psikolojik danışmanın eğitim ortamında öğrenciye bilgi aktarma işlevini başarılı bir şekilde verebilmek için gerekli olan davranışları taşıyabilme konusundaki inancı olarak açıklarken, Senemoğlu, (2005) yeterliği, bireyin gelecekte karşılaşabileceği güç durumların üstesinden gelmede ne derece başarılı olabileceğine ilişkin kendi hakkındaki yargısı, inancı olarak tanımlar.

Sosyal bilişsel kurama bakıldığında yeterlik kavramının ne olduğu ve yeterlik üzerine yapılan çalışmalarda akla gelen ilk isim Bandura olmuştur. Bandura (1986) yeterliği, başlangıçta bireylerin amaçlarına ulaşmak için gerekli davranışları yerine getirme inancı olarak açıklarken, sonraları bireyin bir performansı başarıyla yerine getirmek için gerekli olan 
YYÜ Eğitim Fakültesi Dergisi (YYU Journal of Education Faculty), 2021; 18(1)476-493,http://efdergi.yyu.edu.tr.

eylemleri ve kapasitesi hakkındaki yargıları olarak açıklamıştır. Bandura'ya (1989) göre yeterlik aslında duygusal, bilişsel ve davranışsal becerilerin davranışlara dönüşme biçimleridir. Bandura’nın (1993) yeterlik konusundaki çalışmaları göstermektedir ki yeterlik doğru ya da yanlış olsun, insanların etkinliklerini ve çevresel ortam seçimlerini etkilemektedir. Bireyler baş edemeyeceklerini düşündükleri durumlardan kaçınma eğilimi gösterirken, bir sorunun çözümünde ne kadar süreyle ne kadar çaba sarf edeceklerine dair kararlarını, çözüm için gerekli becerideki yeterlik algıları belirlemektedir. Algılanan yeterlik, etkinlik ve ortam seçimini etkilemekle kalmamakta, aynı zamanda hâlihazırda başlamış olan başa çıkma çabalarını da nihai başarı beklentileri sayesinde etkilemektedir. İnsanların ne kadar çaba sarf edeceğini ve engeller ile olumsuz deneyimler karşısında ne kadar süre dayanabileceğini yeterlik beklentileri belirlemektedir. Algılanan yeterlik ne kadar güçlü olursa çabalar da o kadar etkin olmaktadır (Aksoy ve Diken, 2008).

Günümüz dünyasında bireysel problemler, meslek seçimindeki kararsızlık, ilgi alanlarının çok çabuk değişmesi, karar vermede yaşanan zorluklar, bireysel farklılıklar, seçme hakkındaki özgürlük gibi konular rehberlik hizmet alanlarının varlığını teşkil etmektedir. Tan’a (1990) göre bu hizmet alanları okullardaki rehberlik servisleridir. Ancak Tan, okullarımızda yönetim ve öğretim personeli arasında PDR hizmetlerinin gerçek anlamının ve fonksiyonunun tam olarak anlaşılamadığını ifade etmiştir. Okullarımızda PDR programlarının istenen etki ve verimi sergilememesinde rol oynayan nedenlerden biri olarak yönetici, psikolojik danışman ve öğretmen üçlüsü arasında iyi bir dayanışma, işbirliği ve koordinasyon kurulamamış olmasını göstermektedir.

Bugün okullarda yürütülmekte olan okul psikolojik danışmanlığı hizmetleri psikolojik danışmanlar, öğretmenler, okul idaresi ve veliler ekseninde gerçekleştirilir. Bu hizmetin gerçekleşmesi bir takım çalışmasını gerektirir. Çünkü öğretim hizmetlerini öğretmenler, bu hizmetin düzenini sağlayan idareciler, bu hizmete gerekli desteği veren ebeveynler ve öğrencilerin her türlü gelişimine yardım eden psikolojik danışmanlar ortak hareket etmek zorundadırlar. Sutton ve Fall (1995), psikolojik danışman yeterlik beklentisinde okuldaki öğretmenlerin ve okul yönetiminin önemli belirleyiciler olduğuna değinmişlerdir. Öğretmenlerin okul psikolojik danışmanlarını desteklemelerinin, bunun yanında okul yöneticilerinin okul psikolojik danışmanlığı programına destek vermelerinin ve gerekli materyalleri sağlamalarının okul psikolojik danışmanlarının kendilerini yeterli hissetmelerine olumlu bir etkide bulunduğunu vurgulamışlardır. Dolayısıyla başarılı ve verimli hizmetlerin okul psikolojik danışmanlarının bu unsurlarla işbirliği içerisinde çalışmasıyla gerçekleşir. 
YYÜ Eğitim Fakültesi Dergisi (YYU Journal of Education Faculty), 2021; 18(1)476-493,http://efdergi.yyu.edu.tr.

Oysaki içinde bulunduğumuz yüzyılda psikolojik danışmanların rolleri ve görevleri ile toplumun beklentileri karmaşık bir hal göstermektedir. Değişen topluma ayak uydurmak ve karşılaşılan olumsuzluklarla baş etmek için psikolojik danışmanlık mesleğinin gerekliliği, önemi ve etkililiği iyi irdelenmeli ve toplumun psikolojik danışmanlardan beklentileri de net olmalidir.

Ülkemizde de okul psikolojik danışmanlarının yeterlik beklentileri üzerinde durulmuştur. Örneğin; Yiğit (2001) psikolojik danışmanların yetkinlik düzeylerinin incelenmesi gereken bir konu olduğunu belirtmiştir. Atıcı (2005) da psikolojik danışmanlık mesleğinin, Türkiye’de gelişen ve yaygınlaşan bir meslek olarak kabul edildiğine, okul psikolojik danışmanlığının okullarda hızla yayılan, ancak hak ettiği yere henüz ulaşmamış bir alan olduğuna değinmişlerdir. Bunun, okul psikolojik danışmanlarının kendi rollerini algılayış biçimlerine ve çalışma performanslarına, okuldaki personelin rehberlik anlayışına ve okul psikolojik danışmanlığı çalışmalarını yürütmek için okuldaki gerekli olanaklara dayalı çeşitli nedenleri olabileceğini vurgulamışlardır.

Özgüven’e (2000) göre yurt dışında uygulanan kapsamlı gelişimsel okul psikolojik danışmanlığı programı çerçevesinde değerlendirme süreci için hesap verebilirlik (accountability) kavramı kullanılmaktadır. Ancak ülkemizdeki okullarda uygulanan servis modeli için hesap verebilirlik kavramı kullanılamamaktadır. Hesap verebilirlik kavramı, uygulanan okul psikolojik danışmanlığı programının yeterliğini ölçülebilir terimlerle gösterebilmek için kullanılan bir kavramdır. Ülkemizde bu kavram yerine genellikle değerlendirme kavramı kullanılmaktadır. Değerlendirme konusu literatürde açıklığa kavuşmamış olsa da bu konuda iki farklı anlayışın geliştirildiği görülmektedir. Bunlardan ilki; bir sistem olarak okul psikolojik danışmanlığı servisini değerlendirme (okuldaki psikolojik danışmanlığı servisinin tipi, araç-gereç, personel ve kalite yönünden) ikincisi de; okulda verilen okul psikolojik danışmanlığı hizmetlerinin öğrencilerin yaşam ve davranışları üzerindeki etkileri yönünden değerlendirilmesidir. Çalışmamızın asıl amacı ikinci kısmı kapsamaktadır. Yani okul psikolojik danışmanlarının eğitim-öğretim sürecinde başta öğrencilere ve diğer okul personeline sundukları okul psikolojik danışmanlığının ne ölçüde yeterli olduğudur. Bu amaçla okul psikolojik danışmanlarının kendilerini ne derece yeterli gördükleri algısı ile öğretmenlerin okul psikolojik danışmanlarını ne derece yeterli gördükleri algısı ölçülüp psikolojik danışmanların yeterliği incelenmek istenmiştir. 


\section{YÖNTEM}

\section{Evren ve Örneklem}

Psikolojik danışmanların yeterliğinini konu alan bu araştırmada iki farklı evrenden örneklem çekilmiştir. İlk olarak Van İli Merkez ilçelerinde (Edremit, İpekyolu, Tuşba) görev yapmakta olan okul psikolojik danışmanlar evreninden olasılığa dayalı örneklem yöntemlerinden seçkisiz örnekleme yöntemiyle araştırmaya katılımda gönüllü olan 79 kadın ve 115 erkek olmak üzere toplam 194 psikolojik danışmanı araştırmaya dahil edilmiştir. Bunun yanında arştırmanın ikinci evreninden sosyo ekonomik düzeye göre belirlenmiş okullarda görev yapmakta olan ve araştırmaya katımda gönüllü olan öğretmenler arasından seçkisiz olarak belirlenmiş 192 erkek ve 108 kadın olmak üzere toplam 300 öğretmen araştırmaya dahil edilmiştir. Buna göre bu araştırma, 194 okul psikolojik danışman ve 300 öğretmen olmak üzere toplam 394 kisi üzerinden gerçekleştirilmiştir. Araştırmanın örneklemine ilişkin dağılım Tablo 1 'de gösterilmiştir.

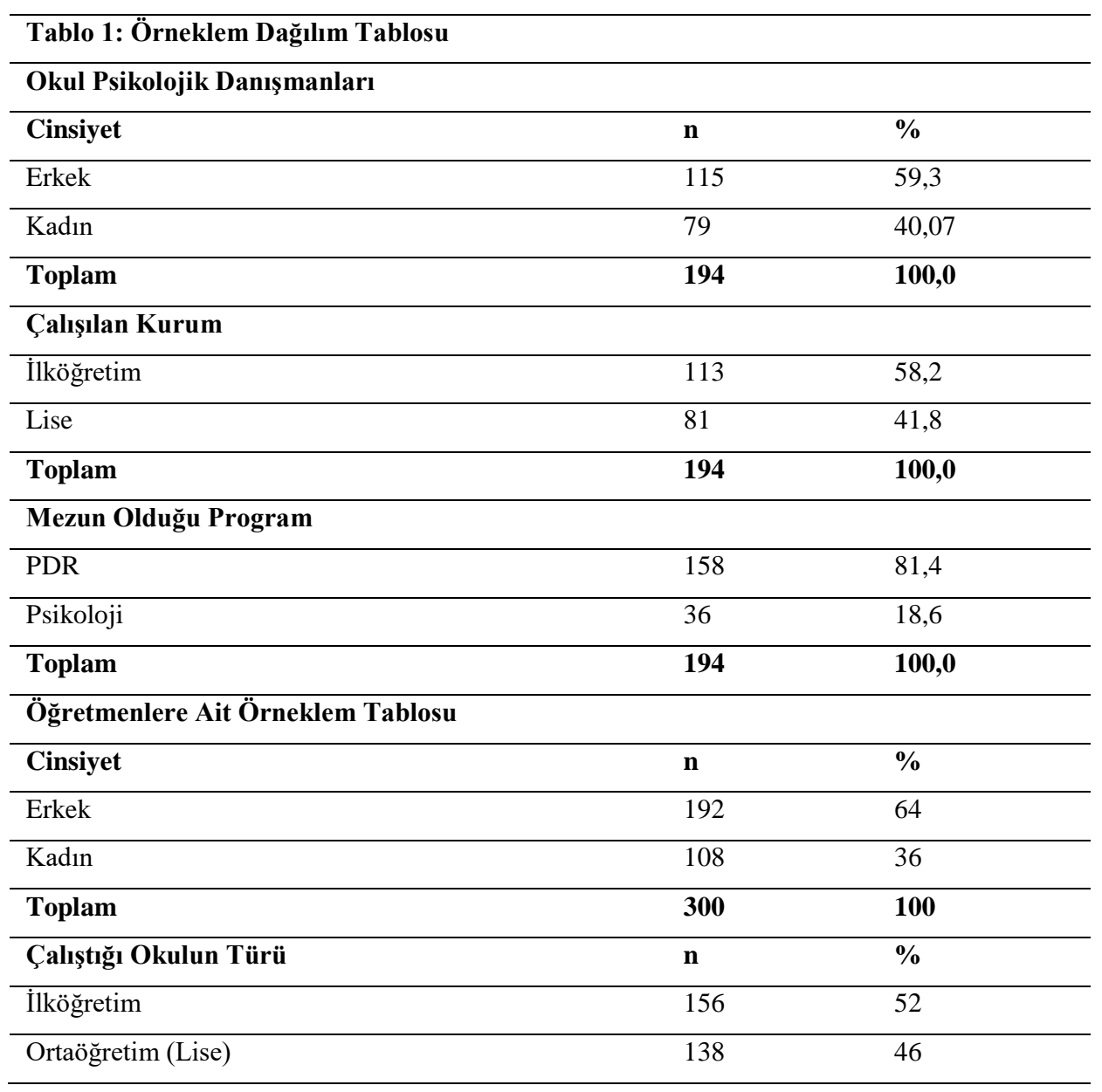


YYÜ Eğitim Fakültesi Dergisi (YYU Journal of Education Faculty), 2021; 18(1)476-493, http://efdergi.yyu.edu.tr, doi:10.33711/yyuefd.882486 Araştırma Makalesi ISSN: 1305-2020

\begin{tabular}{lll}
\hline Anaokulu & 6 & 2 \\
\hline Toplam & $\mathbf{3 0 0}$ & $\mathbf{1 0 0}$ \\
\hline Mezuniyet Alanı & $\mathbf{n}$ & $\mathbf{\%}$ \\
\hline Sınıf Öğretmeni & 73 & 24,3 \\
\hline Branş Öğretmeni & 216 & 72,0 \\
\hline Özel Ĕğtim & 2 & 7,0 \\
\hline Anaokulu & 9 & 3,0 \\
\hline Toplam & $\mathbf{3 0 0}$ & $\mathbf{1 0 0}$ \\
\hline
\end{tabular}

Tablo 1 incelendiğinde Araştırmaya katılan 194 Psikolojik danışmandan; 115'i (\%59,3) erkek, 79’unu $(\% 40,7)$ ise kadınlar oluşturmaktadır. Ölçeğe katılan 194 psikolojik danışmandan; 113 'ü $(\% 58,2)$ ilköğretim okulunda çalışmakta olup, 81'i $(\% 41,8)$ ise ortaöğretimde çalışmaktadır. Ölçeğe katılan 194 Psikolojik danışmandan; 158'i (\%81,4) PDR, 36'sı (\%18,4) psikoloji alanından mezun olmuş kişiler olarak çalışmaktadır. Araştırmaya katılan 300 öğretmenden; 192'si (\%64) erkek, 108'i (\%36) ise kadınlardan oluşmaktadır. Ölçeğe katılan 300 öğretmenden; 156’s (\%52) ilköğretimde çalışmakta olup, 138'i (\%46) ortaöğretim, 6' s1 da (\%2) anaokulunda çalışmaktadır. Ölçeğe katılan 300 öğretmenden; 73’ü’ (\%24,3) sınıf 
YYÜ Eğitim Fakültesi Dergisi (YYU Journal of Education Faculty), 2021; 18(1)476-493, http://efdergi.yyu.edu.tr.

öğretmeni, 216's1 (\%72) branş öğretmeni, 2'si (\%2) özel eğitim öğretmeni, 9'u (\%3) anasınıfi öğretmeni olarak çalışmaktadır.

\section{Kullanılan Ölçme Araçları}

$\mathrm{Bu}$ araştırmada psikolojik danışmanların yeterliğine ilişkin algıları ölçmek amacıyla araştırmacı tarafından geliştirilen "Psikolojik Danışman Yeterlik Algısı Ölçeği” kullanılmıştır. "PDYAÖ” çalışmasına yönelik yapılan geçerlik ve güvenirlik analizleri, okul psikolojik danışmanlığı alınyazın ışığında değerlendirilmiş olup 30 madde ile oluşturulan ölçeğin alg1 düzeyleri beşli likert dereceleme ile ölçeklendirilmiştir. Likert tarzındaki ifadeler; "hiç uygun değil, çok az uygun, kısmen uygun, oldukça uygun, tamamen uygun” biçimindedir. Ölçekten alınacak toplam puan 30 ile 150 arasında değişmektedir. Dört boyutlu açıklanabilen ölçeğimize ilişkin açıklanan varyans (değişimin ölçüsü) \% 47,248 olarak elde edilmiştir. Maddelere ilişkin yük değeri 757 ile 406 arasında değişim göstermiştir. Bu durumda tüm maddelerin .30 kritiğinin üzerinde bir değere sahip olduğu gözlenmiştir. Madde toplam korelasyon değerlerine baktığımızda değerlerin ,576 ile ,740 arasında değiştiği görülmüştür. Ayrıca Pearson'ın geliştirmiş olduğu modelle maddeler arası korelasyonuna bakılmış olup tüm maddelerin ' $\mathrm{P}$ ' değerlerinin ,000 olduğu ve tüm maddelerin çift yıldız (flag) alarak iyi bir düzeyde korelasyona sahip olduğu görülmüştür. Ölçeğe ilişkin yapı geçerliliği ve boyutlandırma işlemleri açımlayıcı faktör analizi ile yapılmıştır. Varimax dik döndürme işlemi sonrasında gerçekleştirilen AFA'ya göre alt boyutlar belirlenmiştir. Ölçeği oluşturan alt boyutlar, araştırmacı tarafından isimlendirilmiştir. Buna göre birinci alt boyut "psikolojik danışma"; ikinci alt boyut "ölçme ve değerlendirme"; üçüncü alt boyut "eğitsel ve mesleki rehberlik" ve dördüncü alt boyut “oryantasyon ve izleme” şeklinde isimlendirilmiştir. Yapı geçerliliği ile önemli ilişkisi olduğu bilinen iç tutarlılık güvenirlik analizi de yapılmış ve elde edilen alfa değerinin yüksek iç tutarl11ığa işaret ettiği tespit edilmiştir $(\alpha=0.96)$. Tüm veriler ve analizler “PDYAÖ” nin yeterli düzeyde geçerli ve güvenilir olduğunu gösterdiğinden ölçek bu çalışmada kullanılmıştır. Öğretmenlere de aynı ölçek (ÖPYAÖ) uygulanmış fakat ölçek maddelerin yüklemleri yeterlik yönünden değiştirilmiştir. Örneğin; psikolojik danışmanlar Likert tipi derecelendirme yapılan ölçekteki maddeyi "yeterliyim” diye puanlarken, öğretmenler "yeterli” diye puan vermişlerdir. Ayrıca bu ölçeğe ait psikolojik danışmanlar için ayrı öğretmenler için ayrı olmak üzere iki farklı "Kişisel Bilgi Formu” (demografik bilgiler) da veri toplama aracı olarak kullanılmıştır.

“PDYAÖ” Van il merkezinde RAM'ın düzenlediği ve tüm il ve ilçelerdeki rehber öğretmenlerin katıldığı bir seminerde, araştırmacı tarafından toplantı yerine gidilerek seminer öncesi 20 dakikalık sürede psikolojik danışmanlara uygulanmıştır. Araştırmacı uygulamada 
YYÜ Eğitim Fakültesi Dergisi (YYU Journal of Education Faculty), 2021; 18(1)476-493, http://efdergi.yyu.edu.tr,

kendisini tanıtmış, araştırmanın amacı hakkında bilgi vermiş ve ölçeğin nasıl cevaplanacağını açıklamıştır. Aynı ölçek öğretmenlerin psikolojik danışmanların yeterliğine ilişkin algısını belirlemek için öğretmenlere de uygulanmıştır. Bu aşamada da, araştırmacı okullara gidip formları öğretmenlere dağıtmış, ölçek için gerekli açıklamaları yapıp veri toplamıştır.

\section{Verilerin Analizi}

İki örneklem grubundan elde edilen veriler SPSS 22.0 paket programı kullanılarak analiz edilmiştir. Frekans yüzde tablolarıyla cinsiyet, çalışılan kurum, mezun olduğu program gibi değişkenlere bakılmış ve sonuçlar tablolaştırılarak verilmiştir. Çalışmadaki örneklem büyüklüğünün uygunluğu kmo ve barlett istatistiği ile onaylanmıştır (kmo $\left.=.967 ; x^{2}=3522,652 ; \mathrm{P}=000\right)$. Ölçekten elde edilen toplam puana ilişkin normallik dağılımı kolmogorov smirnov ile test edilmiştir. Kolmogorov simirnov testine göre $(\mathrm{k}-\mathrm{s}=, 699, \geq 0.05)$ toplam puan değişkenlerinin normal dağılım gösterdiği gözlenmiştir. Homojenlik sayıltısını sınamak için yapilan levene's statistics' e bakılmış olup 'P' değerinin 0.05 ten büyük olduğu, yani homojen olduğu görülmüştür. Kümeleme analizi ile ölçeklerden alınan toplam puanın, hangi aralıklarda kümelenmesinin uygun olacağı belirlenmiştir. Bu yolla, alg1 düzeylerini olumlu, eşik ve olumsuz olmak üzere ayrıntılı bir şekilde görmek mümkün olmuştur.

\section{Bulgular}

Yapı geçerliği ve güvenirliği tamamlanmış olan "PDYAÖ” den elde edilen madde toplamlarına ilişkin tanımlayıcı istatistikler Tablo 3'te gösterilmiştir.

\begin{tabular}{lllllll}
\hline \multirow{2}{*}{$\begin{array}{l}\text { PSIKOLOJIK } \\
\text { DANIŞMAN }\end{array}$} & \multicolumn{2}{c}{ Tablo 3: "PDYAÖ” den elde edilen toplam puanlara ilişkin tanımlayıcı istatistikler: } \\
\cline { 2 - 7 } & Birey Sayısı & Minimum & Maksimum & $\bar{X}$ & Std. Hata & Std. Sapma \\
\cline { 2 - 7 } & 194 & 53.00 & 150.00 & 120,0670 & 1.197 & 16.68174 \\
\hline \multirow{2}{*}{ ÖĞRETMEN } & Birey Sayısı & Minimum & Maksimum & $\bar{X}$ & Std. Hata & Std. Sapma \\
\cline { 2 - 7 } & 300 & 43,00 & 148,00 & 104,7642 & 1,380 & 23,90751 \\
\hline
\end{tabular}

Tablo 3'teki bulgulara göre, 194 psikolojik danışmanın ölçekten almış oldukları puan ortalamasının 120,0670 ve puanlara ilişkin standart sapmanın 16.681 olduğu tespit edilmiştir. Bulgulara göre, 300 öğretmenin ölçekten almış oldukları puan ortalamasının 104,7642 ve puanlara ilişkin standart sapmanın 23,907 olduğu tespit edilmiştir. Yapılan analizlere göre toplam puan değişkeni normal dağılım göstermiştir $(\mathrm{P}=0,699)$. Bu durumda, psikolojik 
YYÜ Eğitim Fakültesi Dergisi (YYU Journal of Education Faculty), 2021; 18(1)476-493, http://efdergi.yyu.edu.tr,

danışmanların ve öğretmenlerin yeterlik algı seviyesi (düşük-orta-yüksek şeklinde), ortalamastandart sapma (düşük seviye); ortalama (orta seviye) ve ortalama + standart sapma (yüksek seviye) şeklinde hesaplanabilir. Ölçek formlarından alınan toplam puanlar homojen olma durumlarına göre iki aşamalı kümeleme analizine tabi tutulmuş olup, her seviyedeki eşik değerler (cut-off) daha detaylı bir şekilde ortaya konabilmiştir. Bu yolla, Yeterlik algı düzeylerinin detaylı bir şekilde ölçülmesi mümkün olabilmektedir. İki aşamalı kümeleme analizi (Two Step Cluster) sonuçları Tablo 4’te gösterilmiştir.

\begin{tabular}{|c|c|c|c|c|c|}
\hline \multirow{6}{*}{$\begin{array}{l}\text { PSİKOLOJIKK } \\
\text { DANIŞMAN }\end{array}$} & \multicolumn{5}{|c|}{$\begin{array}{l}\text { Tablo 4: "PDYAÖ" den elde edilen iki aşamalı kümeleme anal } \\
\text { sonuçları }\end{array}$} \\
\hline & Gruplar & $\mathbf{N}$ & $\mathbf{X}$ & Sd & \% Toplam \\
\hline & 1.Grup (Düşük) & 42 & 96,7381 & 11,30305 & $21,6 \%$ \\
\hline & 2.Grup (Orta) & 77 & 117,1688 & 4,81883 & $39,7 \%$ \\
\hline & 3.Grup (Yüksek) & 75 & 136,1067 & 7,26445 & $38,7 \%$ \\
\hline & Toplam & 194 & 120,0670 & 16,68174 & $100,0 \%$ \\
\hline \multirow{5}{*}{ ÖĞRETMEN } & Gruplar & $\mathbf{N}$ & $\mathbf{X}$ & Sd & \% Toplam \\
\hline & 1. Grup (Düşük) & 112 & 128,9652 & 8,06213 & $37,3 \%$ \\
\hline & 2. Grup (Orta) & 88 & 106,3452 & 6,73281 & $29,3 \%$ \\
\hline & 3. Grup (Yüksek) & 100 & 76,2600 & 11,33923 & $33,3 \%$ \\
\hline & Toplam & 300 & 104,7652 & 23,90752 & $100,0 \%$ \\
\hline
\end{tabular}

Tablo 4'te görüleceği üzere 42 (\%21,6) psikolojik danışmanın \pm 85-107 puan aralığında, 77 psikolojik danışmanın $(\% 39,7) \pm 113-121$ puan aralığında, 75 psikolojik danışmanın $(\% 38,7)$ \pm 129 - 143 puan aralığında oldukları tespit edilmiştir. Kümeleme analizi, ölçekten alınacak toplam puanın, 85 ve 107 aralığını 96,7381, 113 ve 121 aralığını, 117,1688 ve 129 ve 143 aralığını 136,1067 şeklinde kümelenmesini uygun görmüştür. $\mathrm{Bu}$ veriler 1şığında, 194 psikolojik danışmandan 42' sinin psikolojik danışmanların yeterlik algısı hakkında düşük bir algıya sahip olduğunu, 77 psikolojik danışmanın orta düzeyde bir yeterlik algısına sahip olduğunu, 75 psikolojik danışmanın psikolojik danışmanların yeterliği hakkında yüksek bir algıya sahip olduğunu söyleyebiliriz.

Yine tablo 4’te görüleceği üzere 112 (\% 37,3) öğretmenin \pm 120-136 puan aralığında, 88 öğretmenin $(\% 29,3) \pm 100-112$ puan aralığında, 100 öğretmenin $(\% 33,3) \pm 65-87$ puan aralığında oldukları tespit edilmiştir. Kümeleme analizi, ölçekten alınacak toplam puanın, 120 ve 136 aralığını 128,9652, 100 ve 112 aralığını, 106,3452 ve 65 ve 87 aralığını 76,2600 şeklinde 
YYÜ Eğitim Fakültesi Dergisi (YYU Journal of Education Faculty), 2021; 18(1)476-493, http://efdergi.yyu.edu.tr,

kümelenmesini uygun görmüştür. $\mathrm{Bu}$ veriler 1şığında, 300 öğretmenden 112' sinin okul psikolojik danışmanların yeterliği hakkında düşük bir algıya sahip olduğunu, 88 öğretmenin orta düzeyde bir yeterlik algısına sahip olduğunu, 100 öğretmenin psikolojik danışmanların yeterliği hakkında yüksek bir algıya sahip olduğunu söyleyebiliriz.

Tablo 5: Öğretmen-Psikolojik Danışman Çapraz Kümeleme Tablosu

\begin{tabular}{|c|c|c|c|c|c|}
\hline & & \multirow{2}{*}{\multicolumn{3}{|c|}{ PSIKKOLOJİK DANIŞMAN }} & \multirow[t]{3}{*}{ Toplam } \\
\hline & & & & & \\
\hline & & $\overline{A z}$ & Orta & Yeterli & \\
\hline \multirow{6}{*}{ ÖĞRETMEN } & $\mathbf{A z}$ & 15 & 25 & 32 & 72 \\
\hline & & $20,8 \%$ & $34,7 \%$ & $44,4 \%$ & $100,0 \%$ \\
\hline & Orta & 13 & 20 & 18 & 51 \\
\hline & & $25,5 \%$ & $39,2 \%$ & $35,3 \%$ & $100,0 \%$ \\
\hline & Yeterli & 14 & 32 & 25 & 71 \\
\hline & & $19,7 \%$ & $45,1 \%$ & $35,2 \%$ & $100,0 \%$ \\
\hline \multirow[t]{2}{*}{ Toplam } & & 42 & 77 & 75 & 194 \\
\hline & & $21,6 \%$ & $39,7 \%$ & $38,7 \%$ & $100,0 \%$ \\
\hline
\end{tabular}

Tablo 5 incelendiğinde, psikolojik danışmanları az yeterli olarak değerlendiren öğretmenler okul psikolojik danışmanlarının 15'ni \% 20,8 ile az yeterli, 25'ni \% 34,7 ile orta yeterlikte ve 32 'sini \% 44,4 ile yeterli olarak değerlendirmektedir. Buna karşın psikolojik danışmanları orta yeterlikte değerlendiren öğretmenler okul psikolojik danışmanlarının 13'nü \% 25,5 ile az yeterli, 20'ni \% 39,2 ile orta yeterlikte ve 18'ni \% 35,3 ile yeterli olarak değerlendirmektedir. Son olarak psikolojik danışmanları yeterli değerlendiren öğretmenler okul psikolojik danışmanlarının 14'nü \% 19,7 ile az yeterli, 32'ni \% 45,1 ile orta yeterlikte ve 25'ni \% 35,2 ile yeterli olarak değerlendirmektedir. Bununla birlikte daha sağlıklı bir yorum yapabilmek ve iki grubun ölçeğe verdikleri cevapların birbirlerinden bağımsız olup olmadığını öğrenmek için Chi-Square Testine bakılmıştır. Ki kare değeri 2,451 ve testten beklenen değer \% 11,04 olarak elde edilmiştir. Bu durumda ki kare testinin \% 15’ten küçük olma varsayımının karşılandığı görülmektedir. Testin anlamlılık değeri $\mathrm{P}=0,653$ olarak bulunmuştur. $\mathrm{Bu}$ durumda $\mathrm{P}>0,05$ olduğundan, okul psikolojik danışmanları ile öğretmenlerin verdiği cevaplar arasındaki ilişkinin anlamlı olmadığı söylenebilir. Gruplar arasında fark yoksa okul psikolojik danışmanları ile öğretmenlerin verdiği cevaplar ayrışıyor diyebiliriz. 


\section{Tartışma ve Sonuç}

Yalçın (2006), okul psikolojik danışmanının daha olumlu algılanmasını sağlamak amacıyla, okul psikolojik danışmanlarının rollerinin nasıl algılandığını belirlemek için öğretmenler arasında araştırma yapılması ve önceki yıllarda yaptığı etkinlikleri derleyip bu etkinliklerin mesleki imajı geliştirip geliştirmediğini belirlenmesi gerektiğini belirtmektedir. Birçok okul psikolojik danışmanının okulda müdür yardımcısı ya da bir memur gibi görev yaptığına vurgu yapan Sears (1993), ise toplumsal değişim ve beklentilerin farklılaşmasının bir sonucu olarak psikolojik danışmanların öğrencilerin kişisel, sosyal, eğitsel ve mesleki ihtiyaçlarına odaklanması gerektiğini belirtmiştir. Sutton ve Fall (1995), da psikolojik danışman yeterlik beklentisinde okuldaki öğretmenlerin ve okul yönetiminin önemli belirleyiciler olduğuna değinmişlerdir. Öğretmenlerin okul psikolojik danışmanlarını desteklemelerinin, bunun yanında okul yöneticilerinin okul psikolojik danışmanlığı programına destek vermelerinin ve gerekli materyalleri sağlamalarının okul psikolojik danışmanlarının kendilerini yeterli hissetmelerine olumlu bir etkide bulunduğunu vurgulamışlardır. Dolayısıyla başarılı ve verimli hizmetlerin okul psikolojik danışmanlarının bu unsurlarla işbirliği içerisinde çalışmasıyla gerçekleşir. Oysaki içinde bulunduğumuz yüzyılda psikolojik danışmanların rolleri ve görevleri ile toplumun beklentileri karmaşık bir hal göstermektedir. Değişen topluma ayak uydurmak ve karşılaşılan olumsuzluklarla baş etmek için psikolojik danışmanlık mesleğinin gerekliliăi, önemi ve etkililiği iyi irdelenmeli ve toplumun psikolojik danışmanlardan beklentileri de net olmalıdır.

$\mathrm{Bu}$ araştırmada elde ettiğimiz bulgulara göre, alanı isteyerek seçen psikolojik danışmanların yeterlik algıları isteyerek seçmeyen psikolojik danışmanlara göre yüksek çıkmıştır. Ulaştığımız bu sonucu destekleyen Tan'ın (1990) yaptığı bir araştırma sonucuna göre, okul psikolojik danışmanlarının yeterlik algısı “alanı isteyerek seçip seçmediklerine” göre farklılık göstermiştir. Yine Tan (1990) aynı araştırmada, okullarımızda PDR programlarının istenen etki ve verimi sergilememesinde rol oynayan nedenlerden biri olarak yönetici, psikolojik danışman ve öğretmen üçlüsü arasında iyi bir dayanışma, işbirliği ve koordinasyon kurulamamış olmasını göstermektedir. Çalışmamızda ulaştığımız sonuca göre, öğretmenlerin psikolojik danışmanların yeterliğine ilişskin algısı öğrenim düzeyine ve mezun olunan bölüme göre değişmektedir. Yine mezun olunan bölüme göre öğretmenlerin psikolojik danışmanların yeterliğine ilişkin algısı ise tüm alt boyutlarda sınıf öğretmeni ve branş öğretmeni arasında fark bulunmuştur. Lisans mezunu psikolojik danışman ve öğretmenlerin yeterlik algıları lisansüstü eğitim almış psikolojik danışman ve öğretmenlere göre yüksek çıkmıştır. Bu durum eğitim 
YYÜ Eğitim Fakültesi Dergisi (YYU Journal of Education Faculty), 2021; 18(1)476-493,http://efdergi.yyu.edu.tr,

düzeyi ile yeterlik algısı arasında ters bir korelasyonu göstermektedir. Çünkü eğitim düzeyi arttıkça yeterlik algısı düşmüştür.

Psikolojik danışmanların yeterlik algıları ile ilgili elde edilen bulgular ve öğretmenlerin psikolojik danışmanların yeterliğine ilişkin algıları ile ilgili elde edilen bulguları karşılaştırdığımızda; Psikolojik danışmanların yeterlik algısı ile öğretmenlerin psikolojik danışmanların yeterliğine ilişkin algısı "cinsiyete" ve "kıdeme" göre değişmemektedir. Psikolojik danışmanların yeterlik algısı "yaşamınızın büyük çoğunluğunu geçirdiğiniz yere” göre farklılaşmamaktadır. Yani bir okul psikolojik danışmanının köy, kasaba, küçük şehir veya büyük şehirde büyümesi onun yeterlik algısını etkilemediği sonucu ortaya çıkmıştır.

Psikolojik danışmanların yeterlik algısı "mezun olunan bölüme” göre sadece psikolojik danışma alt boyutunda fark bulunmuş diğer alt boyutlarda fark bulunmamıştır. Bu sonuca göre pdr veya psikoloji eğitimi almış okul psikolojik danışmanlarının yeterlik algısı psikolojik danışma alt boyutuna göre fark ediliyorken diğer alt boyutlarda fark edilmiyor. Mezun olunan bölüme göre öğretmenlerin psikolojik danışmanların yeterliğine ilişkin algısı ise tüm alt boyutlarda sınıf öğretmeni ve branş öğretmeni arasında fark bulunmuştur. Psikolojik danışmanların yeterlik algıları ile öğretmenlerin psikolojik danışmanların yeterliğine ilişkin algıları "öğrenim düzeyine” göre lisans ve yüksek lisans değişkenleri açısından farklılaştığı görülmüştür. Ulaşılan bu sonuca göre tüm alt boyutlarda, lisans mezunu okul psikolojik danışmanlar ile lisans mezunu öğretmenlerin yeterlik algıları lisansüstü eğitim almış psikolojik danışman ve öğretmenlere göre yüksek çıkmıştır.

Psikolojik danışmanların yeterlik algısı "çalışılan kuruma” göre farklılaşmamaktadır. Yani anaokulu, ilköğretim ya da lisede çalışmanın okul psikolojik danışmanlarının yeterlik algısını etkilemediği buna karşın öğretmenlerin psikolojik danışmanların yeterliğine ilişkin algısı anaokulu ve ilköğretim ile ilköğretim ve lise arasında fark ediliyorken, anaokulu lise arasında fark edilmiyor.

Psikolojik danışmanların yeterlik algısının "alanla ilgili hizmet içi eğitim alıp almama" değişkenine göre tüm alt boyutlarda farklılaştığı görülmüştür. Bu sonuca göre hizmet içi eğitim alan psikolojik danışmanların yeterlik algıları almayan psikolojik danışmanlara göre yüksek çıkmıştır. Öğretmenlerin psikolojik danışmanların yeterliğine ilişkin yeterlik algıları ise toplam puan ile eğitsel ve mesleki rehberlik alt boyutunda fark bulunmuş diğer alt boyutlarda fark bulunmamıştır. Araştırmada elde edilen bulgulara göre, alanı isteyerek seçen psikolojik danışmanların yeterlik algıları isteyerek seçmeyen psikolojik danışmanlara göre yüksek çıkmıştır. 
YYÜ Eğitim Fakültesi Dergisi (YYU Journal of Education Faculty), 2021; 18(1)476-493, http://efdergi.yyu.edu.tr,

Araştırmada elde edilen bulgulara göre psikolojik danışmanlarının yeterlik algıları “okuldaki öğrenci sayısına” göre sadece psikolojik danışma alt boyutunda farklılık göstermemiştir. Diğer alt boyutlarda farklılık görülmüştür. Öğretmenlerin psikolojik danışmanların yeterliğine ilişkin algıları ise 500 den az ile 1001-1500 ve 2000 öğrenci sayısında anlamlı bir farklılık gösterirken 2000 ve yukarısındaki öğrenci sayısında anlamlı bir farklılık göstermemiştir.

\section{Öneriler}

$\mathrm{Bu}$ çalışmada elde edilen sonuçlara göre, psikolojik danışmanların yeterlik algısı mezun olunan bölüme göre sadece psikolojik danışma alt boyutunda fark bulunmuş diğer alt boyutlarda fark bulunmamıştır. Bu sonuç rehberlik ve psikolojik danışmanlık bölümü mezunları ile diğer bölümlerden mezun olup okullarda psikolojik danışma yapan rehber öğretmenler arasındaki farkı ortaya koymaktadır. Dolayısıyla başka bölümden mezun olup ta psikolojik danışmanlık yapmanın kişilerin mesleki yeterliliğini olumsuz etkilediği sonucuna ulaşılıyor. $\mathrm{Bu}$ nedenle ilköğretim ya da lisede çalışacak psikolojik danışmanların alanda yetişmiş olmaları önerilebilir. Aynı şekilde öğretmenlerin psikolojik danışmanların yeterliğine ilişkin algısı mezun olunan bölüm değişkeni açısından sadece sınıf öğretmeni ve branş öğretmeni arasında fark bulunmuştur. Yani öğretmenlerin okul psikolojik danışmanlarının yeterliğine ilişkin algısı anasınıfı ya da özel eğitim öğretmeni tarafından hiçbir alt boyutta fark edilmiyorken sınıf ve branş öğretmeni algısıyla fark ediliyor. Bu durum öğretmenlerin lisansta aldıkları derslerle alakalı bir durum olabilir. Yani anasınıfı ve özel eğitim öğretmenlerinin sınıf öğretmeni ve branş öğretmenine göre lisansta aldıkları dersler psikolojik danışmanların aldıkları derslere yakınlığı ile ilgili olabilir. Bu durum araştırma konusu olabilir.

Psikolojik danışmanların yeterlik algısının öğrenim düzeyine göre lisans ve yüksek lisans değişkenleri açısından yeterlik alt boyutlarında farklılık görülmüştür. Yani tüm alt boyutlarda lisans mezunu okul psikolojik danışmanlarının psikolojik danışma yapmaya ilişkin yeterlik algıları lisansüstü eğitim almış okul psikolojik danışmanlarına göre anlamlı düzeyde yüksek çıkmıştır. Bu durum okul psikolojik danışmanlarının aldıkları eğitimle ters orantılıdır. Yani aldıkları eğitim artıkça ya da alanda uzmanlaştıkça yeterlik algıları düşmüştür. Öğretmen algısında ulaşılan sonuç da aynı paralelliktedir. Yani öğretmenlerin bilgi seviyeleri artıkça ve alanda uzmanlaştıkça okul psikolojik danışmanlarının yeterliğine ilişkin algıları da düşmüştür. Hâlbuki beklenilen tam tersi bir durumdur. O halde okul psikolojik danışmanlarının lisansta aldıkları eğitimin kalitesi ve yeterliği tartışılabilir. 
YYÜ Ĕ̈itim Fakültesi Dergisi (YYU Journal of Education Faculty), 2021; 18(1)476-493, http://efdergi.yyu.edu.tr,

Psikolojik danışmanların yeterlik algısının alanla ilgili hizmet içi eğitim alıp almama değişkenine göre farklılaştığı görülmüştür. Aynı paralellikte öğretmenlerin de okul psikolojik danışmanlarının yeterliğine ilişkin algısı hizmet içi eğitim alıp almama durumuna göre farklılık gösterdiği görüldü. Yani okul psikolojik danışmanlarının yeterliğine ilişkin hizmet içi eğitim alan psikolojik danışmanlar ve öğretmenler hizmet içi eğitim almayanlara göre yüksek bir algıya sahiptirler. Bu sunuca göre alanla ilgili hizmet içi eğitim almanın gerekliliği önerilebilir.

Araştırmada elde edilen bulgulara göre psikolojik danışmanların yeterlik algısı okuldaki öğrenci sayısına göre alt boyutlarda farklılaşmıştır. Çıkan sonuca göre öğrenci sayısı artıkça okul psikolojik danışmanlarının yeterlik algısı düşmektedir. Bunun en belirgin örneği alt boyutlarda sadece psikolojik danışma boyutunda farkın görülmemesidir. Dolayısıyla psikolojik danışma alt boyutu ölçme ve değerlendirme, eğitsel ve mesleki rehberlik ile oryantasyon ve izleme boyutuna göre bireysel bir çalışma alanı olduğu için bu alt boyuta fark görülmemiştir. $\mathrm{Bu}$ da bize öğrenci sayısı ile psikolojik danışmanların yeterlik algısının ters orantılı olduğu şeklinde bilgi vermektedir diyebiliriz. Bu algının olumluya dönüşmesi için okullardaki öğrenci sayıları azaltılabilir ya da öğrenci mevcudu fazla olan okullardaki psikolojik danışman sayısı norm kadro çerçevesinde arttırılabilir.

Son olarak, bu çalışmada elde edilen bulgular gerek okul psikolojik danışmanlarının gerekse öğretmen algısına göre okul psikolojik danışmanlarının yeterliği değerlendirilmiş, ancak bu hizmetten yaralanan öğrencilerin görüşlerine yer verilmemiştir. Öğrencilerin rehberlik hizmetinden ne derece yararlandıkları üzerine yeni bir araştırma yürütülebilir. Böyle bir çalışmaya öğrencilerin değerlendirmesi de katılarak daha net sonuçlar alınabilir.

\section{Makalenin Bilimdeki Konumu}

Rehberlik ve Psikolojik Danışmanlık Bölümü/Eğitim Bilimleri

\section{Makalenin Bilimdeki Özgünlüğü}

Okul psikolojik danışmanlarının eğitim-öğretim sürecinde başta öğrencilere ve diğer okul personeline sundukları psikolojik danışmanlığın ne ölçüde yeterli olduğu ile ilgili alınyazında çalışmanın olmaması ve psikolojik danışman yeterlik beklentisinde, okuldaki öğretmenlerin önemli belirleyiciler olduğu da gözönünde bulundurulduğunda, okul psikolojik danışmanlarının kendilerini ne derece yeterli gördükleri algısı ile, öğretmenlerin okul psikolojik danışmanlarını ne derece yeterli gördükleri algısı ölçülüp psikolojik danışmanların yeterliğini incelenmek önem arz etmektedir. 
YYÜ Eğitim Fakültesi Dergisi (YYU Journal of Education Faculty), 2021; 18(1)476-493, http://efdergi.yyu.edu.tr.

\section{Kaynaklar}

Aksoy, V. ve Diken, H. (2008). Rehber öğretmenlerin özel ĕgitimde psikolojik danışma ve rehberliğe ilişkin öz yeterlik algıları. Yayımlanmamış yüksek lisans tezi. Eskişehir: Anadolu üniversitesi Eğitim Bilimleri Enstitüsü.

Atıc1, M., Özyürek, R. ve Çam, S. (2005). “Okul danışmanlığı uygulamalarının yetkinlik beklentisi algıları ve mesleki benlik saygısı üzerindeki etkilerinin boylamsal olarak incelenmesi”, Türk Psikolojik Danışma ve Rehberlik Dergisi, c.3, s. 24, ss. 7-23.

Bandura, A. (1982). Self-efficacy mechanism in human agency. American Psychologist. 32(2), $122-147$.

Bandura, A. (1986). Social Foundations of Thought and Action: A Social Cognitive Theory. Englewood Cliffs, NJ: Prentice-Hall Inc.

Bandura, A. (1989). Social Cognitive Theory. Annals of Child Development Six Theories of Child Development. 6. 1-60.

Bandura, A. (1993). "Perceived self-efficacy in cognitive theory”, American Psychologist, 44, 9, 1175-1184.

Özgüven, İ.E. (2000). Çă̆daş eğitimde psikolojik danışma ve rehberlik (2. Baskı). Ankara: PDREM Yayınları.

Sears, S. J. (1993). "The changing scope of practice of the secondary school counselor", The School Counselor, 40, 384-389.

Sutton, J. M. ve Fall, M. (1995). The relationship of school climate factors to counselor selfefficacy. Jornual of Counseling and Development, 73, 331-336.

Senemoğlu, N. (2005). Gelişim öğrenme ve öğretim. Ankara: Gazi Kitabevi.

Şahin, A. E. (2004). Öğretmen yeterliklerinin belirlenmesi. Bilim ve Aklın Aydınlı̆̆ında Ĕ̆gitim Dergisi, 5, 58.

Tan, H. (1990). Okullarımızda psikolojik hizmetlerin neresindeyiz? Türk Psikolojik Danışma ve Rehberlik Dergisi, 1,27-31.

Yalçın, İ. (2006). 21 Yüzyılda psikolojik danışman. Ankara Üniversitesi Ĕgitim Bilimleri Fakültesi Dergisi, 39 (1), 117-133.

Yiğit, F. (2001). “Okul psikolojik danışmanlarının yetkinlik beklentilerini ölçmeye yönelik bir ölçek geliştirme çalışması”, Yüksek Lisans Tezi, Çukurova Üniversitesi, Adana. 


\section{Summary}

\section{Statement of Problem}

Education covers a communicative process. Mutual understanding in bilateral relations strengthens the communication process. Parties' perceptions of competence have an impact on the communication process. Individuals with low proficiency perceptions can remain passive and shy during the communication process, while individuals with high proficiency perception, on the contrary, can take an active and aggressive stance. When this situation is evaluated in terms of education, we can say that teachers' perception of competence affects their performance more actively and successfully. School psychological counseling services in schools today are carried out in the axis of psychological counselors, teachers, school administration and parents. The realization of this service requires a team work. Because teachers, instructors, administrators who provide the order of this service, parents who provide the necessary support to this service and psychological counselors who help students in all kinds of development have to act jointly. Sutton and Fall (1995) mentioned that teachers and school management are important determinants in the expectation of psychological counseling. They emphasized that the support of school psychological counselors as well as the support of school administrators to the school psychological counseling program and providing necessary materials had a positive effect on school psychological counselors' feeling sufficient. Therefore, successful and efficient services are realized by school psychological counselors working in cooperation with these elements.

\section{Method}

This study is a descriptive and relational scanning model, one of the general scanning methods. Universe to determine the perception of the competence of psychological counselors; consists of psychological counselors and teachers working in the province of Van. This study has been studied with two different sample groups. The first sample group consists of 194 psychological counselors, 79 women and 115 men. The second sample group consisted of a total of 300 teachers, 192 males and 108 females. "Psychological Counselor Competency Scale" and "Personal Information Form" were applied to both groups. The data obtained were analyzed in the SPSS program.

\section{Results}

Cluster analysis considered the total score to be obtained from the scale to cluster 85 and 107 intervals between 96,7381, 113 and 121, 117,1688 and 129 and 143 intervals as 136,1067. In the light of these data, it was concluded that 42 of the 194 psychological 
YYÜ Eğitim Fakültesi Dergisi (YYU Journal of Education Faculty), 2021; 18(1)476-493, http://efdergi.yyu.edu.tr,

counselors had a low perception about the counseling perception of the psychological counselor, 77 psychological counselors had a moderate level of perception of counseling and 75 counselors had a high perception about the counseling of the counselor.

Cluster analysis found the total score to be obtained from the scale cluster 120 and 136 intervals as 128,9652, 100 and 112 intervals, 106,3452 and 65 and 87 intervals as 76,2600. In the light of these data, it was concluded that 112 of the 300 teachers had a low perception about the competence of school psychological counselors, 88 teachers had a moderate perception of competence, and 100 teachers had a high perception about the competence of psychological counselors.

\section{Discussion \& Conclusion}

According to the findings; According to the department, in which the psychological counselors' competence perception is graduated, there was a difference only in the psychological counseling sub-dimension and no other sub-dimensions were found. This result reveals the difference between the graduates of the guidance and psychological counseling department and the counselors who graduate from other departments and provide psychological counseling in schools. Therefore, it is concluded that graduating from another department and providing psychological counseling negatively affects the professional competence of the people.

While the perception of teachers about the adequacy of school psychological counselors is not noticed by the kindergarten or special education teacher, it is noticed by the perception of class and branch teachers. This situation may be related to the closeness of kindergarten and special education teachers to the courses taken by the psychological counselors according to primary school teachers and branch teachers. This may be the subject of research.

The perceptions of proficiency of undergraduate graduate school counselors regarding psychological counseling were significantly higher than that of graduate school counselors. This is inversely proportional to the training received by school counselors. In other words, as their education increases or specializes in the field, their perception of competence has decreased. The conclusion reached in the perception of teachers is in the same parallel. In other 
YYÜ Eğitim Fakültesi Dergisi (YYU Journal of Education Faculty), 2021; 18(1)476-493, http://efdergi.yyu.edu.tr,

words, as the level of knowledge of teachers increases and specializes in the field, their perceptions about the sufficiency of school counselors have also decreased. However, the opposite is expected. Therefore, the quality and adequacy of the training that the school psychological counselors receive in the license can be discussed.

Finally, the findings obtained in this study evaluated the adequacy of both the school counselors and the school counselors according to the perception of the teacher, but the opinions of the students who benefited from this service were not included. A new research can be conducted on the extent to which students benefit from the guidance service. More clear results can be obtained by participating in the evaluation of students in such a study. 